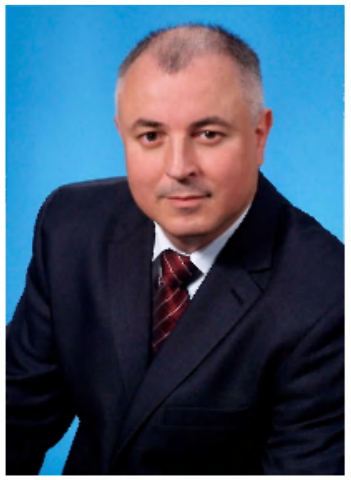

Сергій Полторецький, доктор с.-г. наук, професор кафедри рослинництва,

Уманський національний університет садівництва

e-mail: poltorec@gmail.com

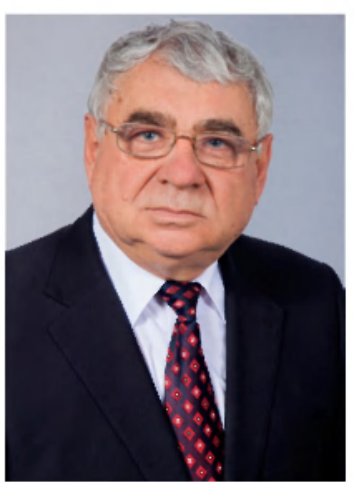
Анатолій Яценко,
доктор с.-Г. наук,
професор кафедри рослинництва,
Уманський національний університет садівництва
e-mail: crop.unuh@gmail.com

\title{
Наталія Полторецька,
} кандидат с.-г. наук доцент кафедри рослинництва, Уманський національний університет садівництва e-mail: poltorec.n@gmail.com

Володимир Білоножко, доктор с.-г. наук, професор кафедри екології та агробіології Черкаський національний університет імені Богдана Хмельницького e-mail: bilonogko1952@gmail.com

Віталій Кравченко, кандидат с.-г. наук, старший викладач кафедри рослинництва, Уманський національний університет садівництва e-mail: vitalii_12@ukr.net

\section{ЕНЕРГЕТИЧНА ЕФЕКТИВНІСТЬ НАСІННИЦЬКИХ חOCIBIB PANICUM MILIACEUM (L.)}

Анотація. Досліджено енергетичну ефективність технології вирощування проса посівного (Panicum miliaceum L.) на насіннєві цілі в поколіннях. Одержаний рівень коефіцієнта енергетичної ефективності вирощування насіння $і$ зерна різних сортів проса посівного вказує на доцільність в умовах Правобережного Лісостепу рекомендованих до виробництва агроприйомів, а також значну економію енерговитрат.

ключові слова: просо посівне, насіння, зерно, енергетична ефективність.

\section{Сергей Полторецкий}

доктор с.-х. наук, профессор, Уманский национальный университет садоводства Наталия Полторецкая

кандидат с.-х. наук, доцент, Уманский национальный университет садоводства

Анатолий Яценко

доктор с.-х. наук, профессор, Уманский национальный университет садоводства

Виталий Кравченко

кандидат с.-х. наук, старший преподаватель кафедры растениеводства Уманский национальный университет садоводства

Владимир Белоножко

доктор с.-х. наук, профессор, Черкасский национальный университет имени Богдана Хмельницкого

\section{ЭНЕРГЕТИЧЕСКАЯ ЭФФЕКТИВНОСТЬ СЕМЕННЫХ ПОСЕВОВ PANICUM MILIACEUM (Lx)}

Исследована энергетическая эффективность технологии выращивания проса посевного (Panicum miliaceum L.) на семенные цели в поколениях. Полученный уровень коэффициента энергетической эффективности выращивания семян и зерна разных сортов проса посевного указывает на целесообразность в условиях Правобережной Лесостепи рекомендованных к производству агроприемов, а также значительную экономию энергопотребления.

ключевые слова: просо посевное, семена, зерно, энергетическая эффективность. 
Serhii Poltoretskyi

Doctor of Agricultural Sciences, Professor of the Department of Plant Production Uman National University of Horticulture Nataliya Poltoretska

PhD in Agricultural Sciences, Associate Professor of the Department of Plant Production Uman National University of Horticulture

Anatoly Yatsenko

Doctor of Agricultural Sciences, Professor of the Department of Plant Production Uman National University of Horticulture V. S. Kavchenko

PhD in Agricultural Sciences, Assistant Lecturer of the Department of Plant Production Uman National University of Horticulture Volodymyr Bilonozhko

Doctor of Agricultural Sciences, Professor of the Department of Ecology and Agrobiology

Cherkasy National University named after Bogdan Khmelnytsky

\section{ENERGY EFFICIENCY OF SEED SOWINGS PANICUM MILIACEUM (L.)}

The energy efficiency of the growing technology of millet (Panicum miliaceum L.) for. seed production in generations has been investigated. The obtained level of the energy efficiency ratio of cultivating seeds and grain of various varieties of browncorn millet indicates the expediency of the recommended agricultural techniques in the conditions of the Right-bank ForestSteppe, as well as the significant energy savings.

Key words: brown-corn millet, seeds, grain, energy efficiency.

Target setting. The economic value and environmental feasibility of any plant production technology is characterized by the level of useful and safe use of energy and other nonrenewable resources [1].

In the conditions of economic instability and growing inflation, the economic evaluation of agricultural production technologies does not provide a full definition of their expediency and the recoupment of capital investments [2]. Therefore, along with the well-known indicators of economic efficiency, it is expedient to carry out an energy estimation. The energy analysis allows determining the energy costs of performing the separate technological operation and comparing the general level of different technologies, as well as the complexes of machines for their implementation, regardless of the pricing policy. Such a versatility of this method of evaluation the effectiveness of the recommended agronomic techniques is of particular importance under the current economic conditions, when the prices for machinery, energy, fertilizers, seeds, plant protection means and other non-renewable sources of energy are rapidly increasing.

The state of studying the issue. The analysis of the peculiarities of the formation of the cereal crops market in Ukraine demonstrates an ever-increasing interest in the purchase of millet from not only domestic consumers, but also the export-oriented companies. Thus, only in the conditions of 2011/2012 marketing year, the millet export has increased more than twice - to 57.8 thousand tons, and according to analysts' forecasts, in subsequent years it may reach 65 thousand tons [3].

The study of the economic and energy efficiency of cereal crops growing in Ukraine was carried out by such leading sciences as 0 . S. Alekseieva, V. Ya. Bilonozhko, $O$. $V$. Averchev and others. However, due to the gradual change of weather conditions and pricing policies, they have partially lost their relevance. In addition, such studies did not take into account the energy efficiency of cereal crops growing for seed purposes. Therefore, in order to solve this problem, the objective of our research was to establish the most suitable and low-energy consuming elements of the technology of high quality seeds growing of various varieties of brown-corn millet.

Statement of basic materials. In order to study the economic and energy efficiency of the elements of the cultivating technology of brown-corn millet varieties for seeds, we have laid a number of field experiments (20032016) in the conditions of the Right Bank Forest-Steppe.

The general indicator of the energy evaluation of the efficiency of crop cultivation is the energy efficiency ratio $\left(\mathrm{K}_{\mathrm{ee}}\right)$, which is calculated as the ratio of the energy received with the yield to its total cost per unit production. The total energy expenditure is defined as the sum of direct (fuel, electricity, gas, coal, etc.) and indirect (cars, fertilizera, seeds, etc.) energy consumptions, expended in vehicles constructions, fertilizers, plant protection means, seeds. It is clear that the production of this or that type of product will be effective only when $k>1$ [4].
Analysis of the performed calculations of the total expenditures of non-renewable energy $(\mathrm{EH})$, its output with the yield of seeds (Ey) and the energy efficiency ratio (Kee) indicate the considerable expediency of the recommended agricultural techniques for the cultivation of millet seeds. In general, according to the results of the conducted calculations, Kee of millet seeds growing was at the level of 3.8-5.6, which is significantly greater than 1 (Table). The high energy value of the cultivated seed $(6069 \mathrm{kcal} / \mathrm{kg})$ contributed greatly to such a high level of this indicator.

Despite the fact that the creation and application of mineral fertilizers is a high-energy consumption process, our proposed dosages provided for the effective product in terms of energy. Thus, in comparison with the nonfertilized control, the expense amount of non-renewable energy consumption on the plots with total fertilizer application $\mathrm{N}_{60} \mathrm{P}_{60} \mathrm{~K}_{60}$ (experiments 1-3) increased from $15.83-16.15 \mathrm{GJ} / \mathrm{ha}$ to $22.29-22.60 \mathrm{GJ} / \mathrm{ha}$, or $40-41 \%$ more. However, a substantial increase in seed yield obtained at the experimental plots provided a significant additional accumulated energy output - at the level of 18.20-40.88 GJ/ha, which is $24-51 \%$ more compared to no treatment.

A similar positive energy effect was also obtained using the optimal sowing parameters of the seed cenosis (Experiments 4 and 5). Thus, the sowing of millet with the usual row method with a seed rate of 3.5 million pcs. of similar seeds/ha in the first and second decades of May provided the energy output with a seed yield of 96.92$118.25 \mathrm{GJ} / \mathrm{ha}$, when $\mathrm{K}_{\text {ee }}=4.3-5.2$. By the wide-row sowing methods at 30 and $45 \mathrm{~cm}$ and the transfer of sowing to the third decade of May, the level of these indicators on the recommended variants of seed rates $(2.5$ and 2.0 million $\mathrm{pcs} / \mathrm{ha}$ ) was somewhat lower and was within the range of 93.78-106.59 $\mathrm{GJ} /$ ha respectively, at $\mathrm{K}_{\mathrm{e}}=3.8-4.4$.

The mowing of seed sowings at $65-70 \%$ of the degree of head maturity with the subsequent swath threshing in three and six days (experiment 6) was almost equivalent to the energy input in the seed yield $(100.22$ and $100.56 \mathrm{GJ} /$ ha), and the threshing delay to $85-90 \%$ of maturity and the direct threshing use somewhat reduced the level of this indicator (by $2 \%$ ).

The variants of the first seed progeny sowings had the significantly lower level of these energy efficiency indices. So, if the total expenses of non-renewable energy remained unchanged $(22,60 \mathrm{GJ} / \mathrm{ha})$, the much lower energy value of the obtained grain yield ( $4046 \mathrm{kcal} / \mathrm{ha}$ ) significantly reduced the amount of energy accumulated in it - according to the level only $39.82-70,98 \mathrm{GJ} / \mathrm{ha}$. However, taking into account that the energy efficiency ratio was greater than $1\left(K_{e \theta}=1,8-\right.$ $3,4)$, the recommended agricultural techniques of the seed material cultivation remained more energy-efficient.

Conclusion. The obtained level of the energy efficiency ratio of seeds $(3,8-5,6)$ and grain $(1,8-3,4)$ growing of various varieties of brown-corn millet shows the expediency of the recommended agricultural techbiques in the conditions of the Right-bank Forest-Steppe and a significant saving of 
Enermefficiente of millet seeds arowin. deandina on the recommended apricultural techniaues

\begin{tabular}{|c|c|c|c|c|c|c|c|}
\hline \multirow{2}{*}{\multicolumn{2}{|c|}{$\begin{array}{c}\text { Variant of the experiment } \\
\text { (variety, millet forecrop, mineral } \\
\text { nutrition system, time and } \\
\text { method of sowing, seeding rate, } \\
\text { harvesting) }\end{array}$}} & \multicolumn{3}{|c|}{ Seed sowing } & \multicolumn{3}{|c|}{ The first seed offspring } \\
\hline & & $\begin{array}{c}\text { Eн, } \\
\text { GJ/ha }\end{array}$ & $\begin{array}{l}\text { Ey, } \\
\text { GJ/ha }\end{array}$ & $K_{\mathrm{ee}}$ & $\underset{G J / h a}{E_{H^{\prime}}}$ & $\begin{array}{l}\text { Ey, } \\
\text { GJ/ha }\end{array}$ & $\mathrm{K}_{\mathrm{ee}}$ \\
\hline \multicolumn{2}{|l|}{1} & 2 & 3 & 4 & 5 & 6 & 7 \\
\hline \multicolumn{2}{|l|}{-} & \multicolumn{3}{|c|}{ Experiment 1 (2003 - 2006 pp.) } & \multicolumn{3}{|c|}{ Experiment 7 (2004 - 2007 pp.) } \\
\hline \multirow{2}{*}{$\begin{array}{l}\text { Veselopodilske } \\
16 \text { variety }\end{array}$} & No fertilizers* & 16,14 & 75,16 & 4,7 & 22,60 & 34,53 & 1,5 \\
\hline & Ground $+\mathrm{N}_{60}$ & 22,60 & 100,83 & 4,5 & 22,60 & 48,32 & 2,1 \\
\hline \multirow{2}{*}{ Golden variety } & No fertilizers* & 16,15 & 80,24 & 5,0 & 22,60 & 37,89 & 1,7 \\
\hline & Ground $+N_{60}$ & 22,60 & 121,12 & 5,4 & 22,60 & 52,14 & 2,3 \\
\hline \multicolumn{2}{|l|}{ Golden variety } & \multicolumn{3}{|c|}{ Experiment $2(2005-2007$ pp. $)$} & \multicolumn{3}{|c|}{ Experiment $8(2006-2008$ pp.) } \\
\hline \multirow{2}{*}{ Forecrop: peas } & No fertilizers* & 16,15 & 89,92 & 5,6 & 22,60 & 56,39 & 2,5 \\
\hline & $\mathrm{N}_{60} \mathrm{P}_{60} \mathrm{~K}_{60}$ & 22,60 & 115,28 & 5,1 & 22,60 & 67,71 & 3,0 \\
\hline \multirow{2}{*}{$\begin{array}{l}\text { Forecrop: winter } \\
\text { wheat* }\end{array}$} & No fertilizers* & 16,15 & 84,00 & 5,2 & 22,60 & 53,42 & 2,4 \\
\hline & $\mathrm{N}_{60} \mathrm{P}_{60} \mathrm{~K}_{60}$ & 22,60 & 112,87 & 5,0 & 22,60 & 63,73 & 2,8 \\
\hline \multicolumn{2}{|c|}{ Poltavske Zolotyste variety } & \multicolumn{3}{|c|}{ Experiment $3(2006-2009$ pp. $)$} & \multicolumn{3}{|c|}{ Experiment $9(2007-2010 \mathrm{pp})}$. \\
\hline \multirow{4}{*}{$\begin{array}{l}\text { Common row } \\
\text { sowing method } \\
(15 \mathrm{~cm})\end{array}$} & No fertilizers* & 16,13 & 76,01 & 4,7 & 22,59 & 45,15 & 2,0 \\
\hline & $P_{60}$ & 16,88 & 76,35 & 4,5 & 22,59 & 59,26 & 2,6 \\
\hline & $\mathrm{N}_{60} \mathrm{~K}_{60}$ & 21,83 & 89,13 & 4,1 & 22,59 & 57,37 & 2,5 \\
\hline & $\mathrm{N}_{60} \mathrm{P}_{60} \mathrm{~K}_{60}$ & 22,60 & 94,21 & 4,2 & 22,59 & 51,38 & 2,3 \\
\hline \multirow{4}{*}{$\begin{array}{l}\text { Wide-row sowing } \\
(45 \mathrm{~cm})\end{array}$} & No fertilizers* & 15,83 & 70,76 & 4,5 & 22,59 & 43,20 & 1,9 \\
\hline & $P_{60}$ & 16,59 & 79,39 & 4,8 & 22,59 & 57,44 & 2,5 \\
\hline & $\mathrm{N}_{60} \mathrm{~K}_{60}$ & 21,53 & 80,94 & 3,8 & 22,59 & 52,19 & 2,3 \\
\hline & $\mathrm{N}_{60} \mathrm{P}_{60} \mathrm{~K}_{60}$ & 22,29 & 92,20 & 4,1 & 22,59 & 61,13 & 2,7 \\
\hline \multicolumn{2}{|l|}{-} & \multicolumn{3}{|c|}{ Experiment $4(2009-2012$ pp.) } & \multicolumn{3}{|c|}{ Experiment $10(2010-2013$ pp. $)$} \\
\hline \multirow{2}{*}{$\begin{array}{l}\text { Slobozhanske } \\
\text { variety, Common } \\
\text { row sowing } \\
\text { method }\end{array}$} & first term & 22,62 & 96,92 & 4,3 & 22,62 & 61,54 & 2,7 \\
\hline & second term* & 22,62 & 106,82 & 4,7 & 22,62 & 55,07 & 2,4 \\
\hline Wide-row sowing & third term & 22,31 & 97,26 & 4,4 & 22,62 & 57,01 & 2,5 \\
\hline \multirow{2}{*}{$\begin{array}{l}\text { Lana variety, } \\
\text { Common row } \\
\text { sowing method }\end{array}$} & first term & 22,62 & 102,84 & 4,5 & 22,62 & 70,98 & 3,1 \\
\hline & second term* & 22,62 & 112,66 & 5,0 & 22,62 & 56,71 & 2,5 \\
\hline Wide-row sowing & third term & 22,31 & 98,78 & 4,4 & 22,62 & 61,68 & 2,7 \\
\hline \multicolumn{2}{|l|}{ Omriiane variety } & Exper & $5(2008$ & $\left.\partial p_{2}\right)$ & Experin & $(2009-$ & $p p)$. \\
\hline $\begin{array}{l}\text { Звичайний ряд- } \\
\text { ковий спосіб }\end{array}$ & $\begin{array}{l}3.5 \text { million } \\
\text { pcs./ha }\end{array}$ & 22,62 & 118,25 & 5,2 & 22,62 & 72,55 & 3,2 \\
\hline$(15 \mathrm{CM})$ & $\begin{array}{l}4.0 \text { million } \\
\text { pcs./ha* }\end{array}$ & 22,73 & 124,25 & 5,5 & 22,62 & 50,65 & 2,2 \\
\hline Широко-рядний & $\begin{array}{l}2.5 \text { million } \\
\text { pcs./ha }\end{array}$ & 22,41 & 98,02 & 4,4 & 22,62 & 73,99 & 3,3 \\
\hline & $\begin{array}{l}3.0 \text { million } \\
\text { pcs./ha* }\end{array}$ & 22,52 & 106,59 & 4,7 & 22,62 & 56,31 & 2,5 \\
\hline Широко-рядний & $\begin{array}{l}2.0 \text { million } \\
\text { pcs./ha }\end{array}$ & 22,31 & 84,05 & 3,8 & 22,62 & 76,12 & 3,4 \\
\hline & $\begin{array}{l}2.5 \text { million } \\
\text { pcs./ha* }\end{array}$ & 22,41 & 93,78 & 4,2 & 22,62 & 67,48 & 3,0 \\
\hline Golden variety & & Exper & $6(2012$ & pp.) & Experin & $(2013-$ & pp.) \\
\hline Degree of & $\begin{array}{c}3 \text { days of } \\
\text { swath storing }\end{array}$ & 22,60 & 100,22 & 4,4 & 22,60 & 61,62 & 2,7 \\
\hline $\begin{array}{l}\text { seed maturity } \\
65-70 \% *\end{array}$ & $\begin{array}{l}6 \text { of swath } \\
\text { storing } *\end{array}$ & 22,60 & 100,56 & 4,4 & 22,60 & 60,73 & 2,7 \\
\hline & $\begin{array}{c}\text { direct } \\
\text { threshing }\end{array}$ & 19,51 & 98,35 & 5,0 & 22,60 & 39,82 & 1,8 \\
\hline
\end{tabular}

Note. * - control 
energy costs.

\section{References}

1. Buzovskiy E. A. Vitvitska O. D., Skrippicheiko B. A. (2008). Innovatsiyi v otsinyuvanni energetichnoyi efektivnosti ta energoemnosti silskogospodarskogo virobnitstva [Innovations in the assessment of energy efficiency and energy intensity of agricultural production]. Agroinkom. Kiev, №. 7-10, pp. 50-56. (In Ukrainian).

2. Brazhevska G. M. (2011). Ekonomiko-energetichna otsinka virobnichih protsesiv u roslinnitstvi [Economic and energy assessment of production processes in crop production]. Ekonomika APK, №1, pp. 65-70. (In Ukrainian).
3. Protsiv S. (2012). Ukrainskiy ryinok prosa: kogda rezultatyi ne opravdyivayut ozhidaniya (2011/2012/2013 MG) [Ukrainian millet market: when the results do not justify expectations (2011/2012/2013 marketing year)]. APKInform. Rezhim dostupu $z$ ekranu: http://www.apk-inform.com/ru/exclusive/ topic/1010122\#

Usa4e7Tf8RI. (In Russian).

4. TararIko Yu. O., Nesmashna O. Yu., Berdnikov O. M. et al. (2005) Bioenergetichna otsinka silskogospodarskogo virobnitstva (naukovo-metodichne zabezpechennya) [Bioenergy evaluation of agricultural production (Scientific and methodological support)]. Kiev: Agrarna nauka, 200 p. (In Ukrainian). 